\title{
Economics feasibility of coconut cultivation in Karnataka
}

\author{
M.S. KISHORE AND C. MURTHY
}

Received : 05.08.2017; Revised : 11.09.2017; Accepted : 25.09.2017

\begin{abstract}
The present study was undertaken in Tumkur and Hassan districts of Karnataka during the year 2015-16, with the objective of studying the economics and feasibility of coconut cultivation. Multistage sampling method was used for the study. The sample size was 80 farmers. Tabular analysis and financial feasibility tools like NPV, IRR, B:C ratio and PBP were used for analysis. The results revealed that initial investment on coconut plantation worked out to of Rs. 63,708 per hectare. The total maintenance cost during gestation period was found to be Rs. 4,68,750 and the total cost of establishing one hectare of coconut plantation was Rs. 5,37,266. The total cost of cultivation of coconut during bearing period was Rs. 1,61,827 per hectare. The total cost of cultivation of copra was Rs. 1, 67,580 per hectare. It was observed that the per quintal cost of cultivation of copra worked out to of Rs. 8,480. The net return from copra was the highest at Rs. 22,856 per hectare, followed by the second highest net returns from tender nuts (21,591 per hectare) and lastly returns from mature nuts ( 905 per hectare). The net present value at the end of the economic life of the project viz., 50 years was found to be Rs. 3,76,861 per hectare at 10 per cent discount factor. The project on coconut cultivation had an internal rate of return of 13.3 per cent over its economic life. It was observed that the payback period of coconut cultivation was 21.8 years. The benefit cost ratio of coconut plantations was found to be 1.18 .
\end{abstract}

KEY WORDS : Coconut, Maintenance cost, Cost of cultivation, Feasibility, Copra, Net present value, B:C ratio, Internal rate of return, Pay back period

How to cite this paper : Kishore, M.S. and Murthy, C. (2017). Economics feasibility of coconut cultivation in Karnataka. Internat. J. Com. \& Bus. Manage, 10(2) : 243-249, DOI: 10.15740/HAS/IJCBM/10.2/243-249. 